$$
\begin{aligned}
& \text { 係員 } 5 \text { 名 } \\
& \text { 作業員 } 40 \text { 名 }
\end{aligned}
$$

$$
\text { 9. 結言 }
$$

生野工場における錫製鍊の概要を記述したが，今後とも国内鉱 山出の錫㳯は漸時減少傾向にあるので, 各種の錫涬を積極的に集
め, 錫資源のリサイクルに努めて, 生産を確保して行きたい。ま た，錫㳯の性状等も今後ますます多様化してくるものと思われる。 それに対応した錫の有利回収技術の開発に努めて行かねばならな W。

さらに，現状の操業方式においては，多量の電力を消費するの

で，今後省エネルギーの面からも新製鍊法の検討が必要である。

\title{
Tin Smelter at Ikuno Plant
}

by Toshio SUGANUMA and Masao KUWABARA

Ikuno tin smelter started its operation in 1913 with the reverberatory furnace smelting process and in 1916 another plant started to recover tungsten which was contained in tin concentrates in the form of scheelite.

In 1950, the company replaced the reverberatory furnace with an electric furnace to improve operation efficiency and recovery.

The smelting process is composed of three stages, namely, concentrate smelting, slag smelting, and hard-head smelting. At present, smelter treats both tin concentrates mainly from Akenobe Mine and other tin bearing scrap materials to recover tin metal.

Annual production of crude tin metal is approximately 1,250 metric tons and $50 \%$ of the crude metal comes from tin bearing scrap materials.

- Ikuno is the only primary tin smelter in Japan.

\section{〔3-8]直島製錬所の電気錫製鍊}

斎 藤 臣 $^{1}$

\section{1. 緒言}

沿革 : 三菱金属生野鉱業所 ( 現生野工場 )にて乾式製鍊された 粗錫は，昭和 34 年 10 月まで大阪製鍊所において電解精製され電 気錫とされていたが，その後錫電解工場は直島製鍊所に移設され， 昭和 35 年 2 月より当製鍊所において電気錫の生産を開始し現在に 至つている。本邦最大の電気錫製鍊工場である。

\section{2. 生産量, 操業系統, 操業条件, 主要設備}

\section{$2 \cdot 1$ 生産能力}

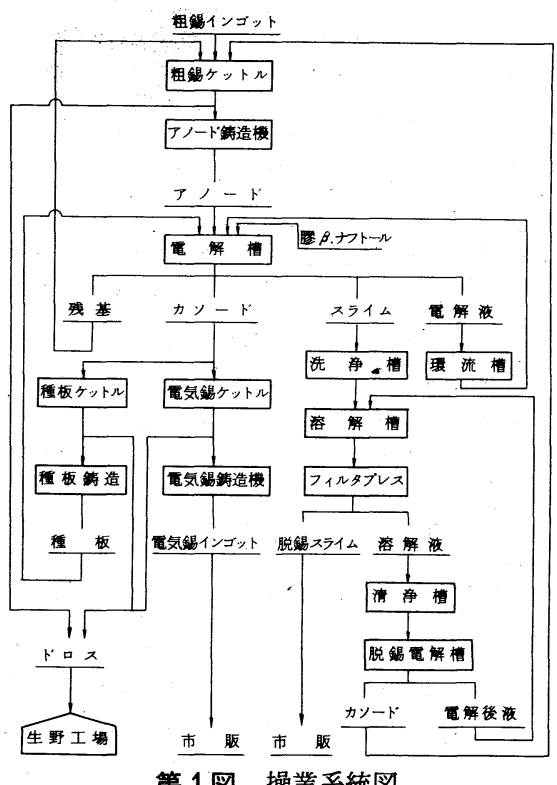

第1図 操業系統図
電気錫 $122 \mathrm{t} /$ 月（60槽 $1350 \mathrm{~A}$ 通電の場合）

\section{$2 \cdot 2$ 生産量}

原料生野粗錫 $110 \mathrm{t} /$ 月 産出電気錫 $106 \mathrm{t} /$ 月

\section{$2 \cdot 3$ 操業系統}

第 1 図参照

$2 \cdot 4$ 操業条件

アノード サイズ $725 \mathrm{mmW} \times 770 \mathrm{mmH}$

重 量 $128 \mathrm{~kg} /$ 枚

枚 数 24 枚 / 槽

ピッチ $105 \mathrm{~mm}$

ライフ 36 日

残基率 $25 \%$

カソード 種板サイズ $730 \mathrm{mmW} \times 740 \mathrm{mmH}$

\begin{tabular}{|c|c|c|c|}
\hline 称 & 様 & 台数 & 能 力 \\
\hline アノード鋳造 機 & $\begin{array}{l}\text { 回転鋳造機, テーブル径 } 5.5 \mathrm{~m} \\
\text { モールド } 12 \text { 枚, } 5.5 \mathrm{~kW} \text { G.M. }\end{array}$ & 1 & $8 \mathrm{t} / \mathrm{h}$ \\
\hline 電気錫 鋳 造 機 & 自動走行式, モールド 66 個 & 1 & $7 \mathrm{t} / \mathrm{h}$ \\
\hline 電解 槽 & $\begin{array}{l}\text { 鉄筋 コンクリート, アスファルトライ=ング } \\
\text { 内寸 } 2700 \mathrm{mmL} \times 800 \mathrm{mmW} \times 900 \mathrm{mmH} \\
4 \mathbf{E}_{\mathbf{Z}} \text { カスケード方式 }\end{array}$ & 60 & $122 \mathrm{t} /$ 月 \\
\hline シリコン整流機 & $\begin{array}{ll}\text { 屋内風冷式 } & 30 \mathrm{~V}-10 \mathrm{~V}, 1500 \mathrm{~A} \\
\text { 変流効率 } & 85 \%\end{array}$ & & \\
\hline $\begin{array}{l}\text { (スライム処理 ) } \\
\text { フィルタプレス }\end{array}$ & クリタ式RF 10 型完全自動フィルタプレス & 1 & \\
\hline 脱 錫 電 解 槽 & $\begin{array}{l}\text { 鉄筋コンクリート, アスファルトライ=ング } \\
\text { 内寸 } 2700 \mathrm{mmL} \times 800 \mathrm{mmW} \times 900 \mathrm{mmH}\end{array}$ & 4 & \\
\hline
\end{tabular}

種板重量 $2 \mathrm{~kg} /$ 枚 - (電気錫製)

第1表 主 要 設 備

1. 正会員 三菱金属侏式会社直島製鍊所錫製鍊課長 
第 2 表 分 析 品 位

\begin{tabular}{c|c|c|c|c|c}
\hline 成 分 & $\mathrm{Sn}$ & $\mathrm{Fe}$ & $\mathrm{Cu}$ & $\mathrm{F} b$ & $\mathrm{As}$ \\
\hline 粗 錫 & $97.5 \%$ & $0.1 \%$ & $1.0 \%$ & $0.8 \%$ & $0.4 \%$ \\
電気錫 & $>99.995 \%$ & $<15 \mathrm{ppm}$ & $<10 \mathrm{ppm}$ & $<10 \mathrm{ppm}$ & $\mathrm{tr}$ \\
スライム & $18 \%$ & $2 \%$ & $20 \%$ & $16 \%$ & $8 \%$ \\
\hline
\end{tabular}

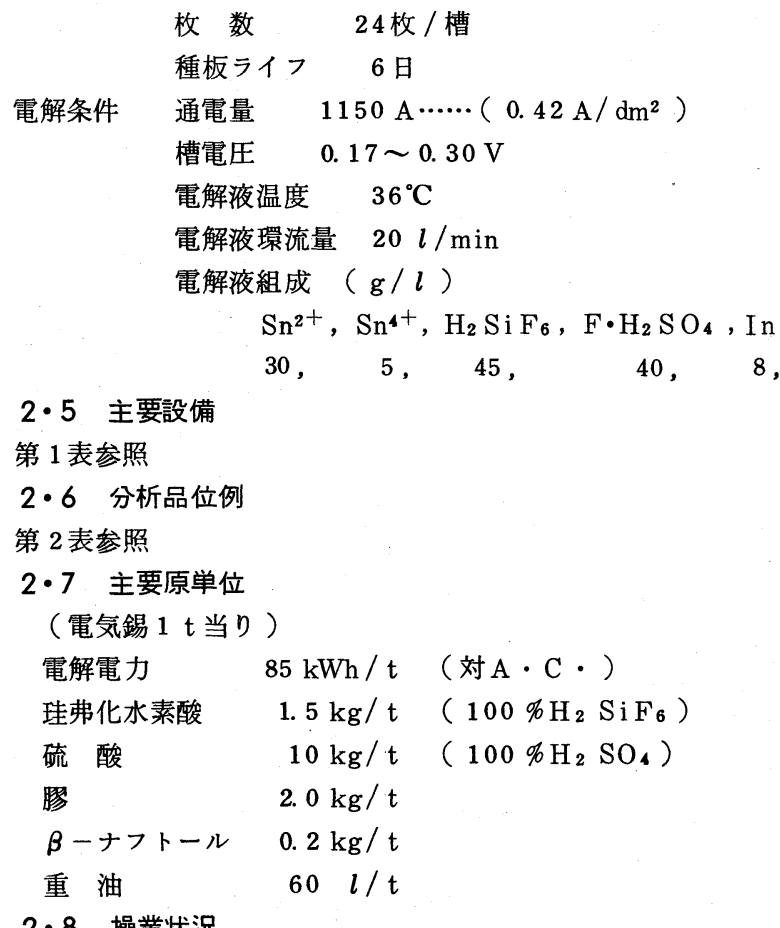

$2 \cdot 8$ 操業状況

昭和 35 年 2 月以降 37 年 10 月まで電流 $900 \sim 1,100 \mathrm{~A}$, 電流 密度 $0.5 \sim 0.6 \mathrm{~A} / \mathrm{dm}^{2}$, カソード枚数 21 枚/槽, 電槽数 52 槽,
生産量70〜80 t/月で操業してきたが 37 年 9 月錫増産の必要に迫 られ 8 槽の増槽を行なつた。37 年 10 月極間距離を $115 \mathrm{~mm}$ から $110 \mathrm{~mm}$ に短縮し, 1 槽当りカソード枚数を 23 枚に増やすと同時 に, 通電電流も $1,200 \mathrm{~A}$ に上昇せしめ, 電流密度 $0.63 \mathrm{~A} / \mathrm{dm}^{2}$ と し, 生産量 $100 \sim 105 \mathrm{t} /$ 月となつた。さらに 40 年 3 月還流液出 入口を改造, かつピッチを $105 \mathrm{~mm}$ に短縮しカソード枚数 24枚/ 槽と 1 枚增やし, 電流密度を据置き電流を $1,250 \mathrm{~A}$ と上昇せしめ た結果, 生産能力は $110 \mathrm{t} /$ 月と增大した。その後 48 年 9 月には さらに増産の必要に迫られ, アノードおよびカソードのサイズを 縦方向にそれぞれ $80 \mathrm{~mm}$ 拡大し, 通電量を $1350 \mathrm{~A}$ に上げること によつて, 生産能力は現在の $122 \mathrm{t} /$ 月となつた。

\section{$2 \cdot 9$ 副産物の回収}

粗錫中の不純物の一つであるインジウムは電解液中に濃縮し, $18 \sim 20 \mathrm{~g} / l$ 以上になると電気錫の品質にも悪影響を及ぼしか ねず, 昭和 49 年 3 月まで電解液よりインジウムメタルの回収を行 なつていた。その後粗錫中のインジウム濃度の低下およびインジ ウム価格の下落により回収利点が薄れ中断していたが, 54 年 8 月 より, メタル価格の高騰に伴い再開したが, 液中のインジウム濃 度が低く $(8 \mathrm{~g} / l) 55$ 年 4 月に中断した。

またスライムからの有価金属回収についても過去種々試みられ てきたが，少量であるため採算悪く，現在外販している。

\section{3. 今後の問題点}

国内における錫資源は非常に乏しく, 特に将来鉱石原料の入手 は困難であろう。これが対策としてはスクラップ, 涬類に原料を 求めざるを得ず, この結果粗錫中の不純物は多種多彩にわたるも のと思われる。しかしながら現在の錫電解技術ではこれらに対応 しうるまで至つておらず, 今後の課題はこれらを対象とした低品 位粗錫の電解精製技術の確立にかかつているといえる。

Tin Refining at Naoshima Smelter

by Hideomi SAITO

The tin refining plant at Naoshima Smelter began operation in 1960 treating crude tin produced at Ikuno Smelter, while the tin refining plant at Osaka Refinery was shut down.

At the present time, the plant, the only primary tin refinery in Japan, produces electrolytic tin of more than $99.995 \%$ at a capacity of $130 \mathrm{t} / \mathrm{m}$.

\section{〔3-9〕 三菱軽金属直江津工場におけるアルミニウム製鍊}

\section{1. 緒言}

当直江津工場は天然ガスによる直流エンジンの自家発電を特徵

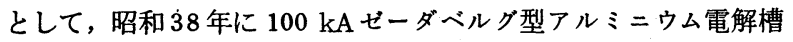
の操業を開始, 昭和 45 年には 4 系列, 年産 $162,000 \mathrm{t}$ の生産能力 を持つに至つた。その後発電は天然ガスの減少により, 逐次重油 発電へと切り替わつた。

昭和 48 年の第 1 次オイルショックは電力多消費産業であるアル ミニウム製鍊業に多大な影響を与え, 生産能力を充分に活かすこ となく推移しているのが実情である。また, 最近では重油価格の

1. 三菱軽金属工業株式会社直江津工場製造一部部長代理

\section{細井久 孝}

高騰により直流エンジン発電の利点が十分に発揮できないが, 化 石燃料発電方式の中でアルミニウム製鍊用電源としての特長は依 然評価できる。

アルミニウム製鍊における省エネルギーは主に電解槽の設計技 術の発達により, 新鋭工場の効率の良い大容量電解槽の採用によ つて達成されてきた。当社も設計技術を修得し, 電解槽で使用す る材料の改良, 運転方法の改良を実施し, 近年急激な省エネルギ 一を果している。

2. アルミニウム製錬の概要

\section{$2 \cdot 1$ 製錬方法の概要}

日本鉱業会誌/97 1122('81-8) $775<175>$ 